\title{
ANALISIS DAMPAK COVID-19 DALAM PROSES PEMBELAJARAN DARING PADA KELAS B4 DI PAUD TELKOM TERNATE
}

\author{
Sri Winarti1, Bahran Taib², Bujuna Alhadad3, Fatoni Achmad4 \\ Universitas Khairun \\ Fakultas Keguruan Dan Ilmu Pendidikan \\ Jl.Bandara Sultan Babulla Kota Ternate Utara, Kode Pos 53 Ternate 97728 \\ Telepon (0921)3110905-Faksimili 0921-3110901 \\ Email: winapurnama197@gmail.com
}

\begin{abstract}
Abstrak: Penelitian ini bertujuan untuk menganalisis dampak Covid-19 dalam proses pembelajaran daring di rumah pada siswa kelas B4 di PAUD Telkom Ternate. Jenis penelitian ini adalah deskriptif kualitatif yaitu penelitian yang di tujukan untuk mendeskripsikan dan menganalisis tentang fenomena atau aktivitas sosial. Teknik pengumpulan data yang digunakan adalah wawancara, dan dokumentasi. Berdasarkan hasil penelitian dampak Covid-19 dalam proses pembelajaran daring tidak hanya terjadi pada anak namun juga pada orang tua dan guru, yaitu stres yang dialami oleh anak dan orang tua. Selain itu anak juga mengalami penurunan capaian perkembangan, kehilangan semangat belajar, beresiko kehilangan pembelajaran, serta korban kekerasan verbal. Sedangkan dampak yang dirasakan oleh guru yaitu kurang optimalnya dalam proses penilaian perkembangan terhadap anak.
\end{abstract}

Kata Kunci: Covid-19, Pembelajaran Daring, Anak

Abstract: This study aims to analyze the impact of Covid-19 in the online learning process at home in grade B4 students at PAUD Telkom Ternate. This type of research is descriptive qualitative which aimed at describing and analyzing social phenomena or activities. The data collection techniques used were interviews and documentation. Based on the results of research on the impact of Covid-19 in the online learning process, it does not only affect children but also parents and teachers; the children and the parents were stress in facing the situation. In addition, children also had a declining developmental achievement, lost their learning motivation, were at risk of losing learning, and became the victims of verbal violence. Meanwhile, the impact felt by the teacher was less optimal in the process of assessing the development of children.

Key Words: Covid-19, Online Learning, children

\section{A. Pendahuluan}

Dunia saat ini disibukkan dengan munculnya sebuah virus baru yang berasal dari Wuhan China yang bernama Virus Corona (Covid-19). Terhitung tanggal 1 Juli 2020 virus ini telah menginfeksi 19.293 .503 orang, dengan jumlah kematian 718,328 jiwa dan jumlah pasien yang sembuh 12,385,834 orang serta menginfeksi 213 negara (worldometers.info, 2020). Di Indonesia sendiri, penyebaran virus ini ditemukan pertama kali pada tanggal 2 maret 2020, hal ini disampaikan langsung oleh Presiden Joko Widodo (kompas.com, 2020), sampai tanggal 1 juli 2020 covid-19 telah menginfeksi sebanyak 57.770 orang dengan jumlah kematian 2.934 jiwa, dan jumlah pasien yang sembuh sebanyak 25.595 orang. 
Kemunculan covid-19 ini sangat mempengaruhi kehidupan masyarakat dan menimbulkan banyak kepanikan. Ratusan bahkan ribuan manusia yang telah terinfeksi dan sudah banyak yang meninggal dunia akibat virus ini. Dalam hal ini pemerintah tidak tinggal diam, mulai dari memberikan banyak himbauan-himbauan dan bantuan kepada masyarakat dalam mengatasi wabah Corona-19 ini agar berjalan efektif dan efisien. Pemerintah Indonesia menerapkan sistem dirumah aja sebagai upaya memutus mata rantai penyebaran virus ini, salah satunya yaitu dengan mengeluarkan PP Nomor 21 Tahun 2020 tentang Pembatasan Sosial Berskala Besar (PSBB) dalam rangka percepatan penanganan Covid-19, masyarakat Indonesia diharuskan untuk diam dan bekerja dirumah masing-masing tak terkecuali dalam bidang pendidikan. Dengan adanya aturan ini membuat para pekerja dan buruh pabrik terpaksa diam dirumah, dikurangi gajinya, dan beberapa perusahaan melakukan PHK (Pemutusan Hubungan Kerja) padahal masih produktif untuk bekerja sehingga Covid19 tidak hanya berdampak pada kesehatan, tetapi juga pada finansial dan psikologis.

Sementara itu dalam bidang pendidikan, peraturan tentang aktivitas Belajar Dari Rumah (BDR) secara resmi telah di keluarkan melalui surat edaran Mendikbud No. 36962 / MHK.A / HK / 2020 tentang pembelajaran secara daring dan bekerja dari rumah dalam rangka pencegahan penyebaran Corona Virus Disiase (Covid-19). Kebijakan ini memaksa guru dan murid untuk tetap bekerja dan belajar dari rumah dari jenjang PAUD sampai perguruan tinggi (kemendikbud.go.id, 2020). Kebijakan ini tidak hanya berdampak pada relasi guru dan murid selama BDR, namun juga pentingnya optimalisasi peran orang tua dalam pelaksanaan BDR.

Pandemi Covid-19 ini telah mengubah pola pembelajaran yang semestinya tatap muka menjadi pembelajaran jarak jauh atau biasa di sebut daring. Sekaitan dengan dampak Covid-19 terhadap pembelajaran daring penelitian-penelitian yang telah membuktikan bahwa wabah ini mempengaruhi proses pembelajaran online telah dilakukan oleh Arifah dan Iis (2020) dalam jurnal Pendidikan Anak Usia Dini dengan judul "Persepsi Guru Dampak Pandemi Covid-19 terhadap Pelaksanaan Pembelajaran Daring di PAUD". Penelitian ini menggunakan metode studi kasus dengan menggunakan pendekatan kualitatif dengan hasil bahwa pembelajaran daring dalam pandemi covid ini kurang efektif karena mengalami berbagai hambatan seperti penyampaian materi yang kurang maksimal, beban pembelian kuota internet, koneksi internet yang kadang menjadi lamban, gaya belajar yang cenderung visual, serta kurang leluasanya guru dalam mengontrol kegiatan siswa. Berbeda dengan penelitian yang dilakukan oleh Arifah dan Iis (2020), sebaliknya penelitian Dewi (2020) dalam jurnal ilmu pendidikan dengan judul "Dampak Covid-19 terhadap implementasi pembelajaran daring", menunjukkan bahwa dampak covid-19 terhadap implementasi pembelajaran daring di sekolah dasar dapat terlaksanakan dengan cukup baik apabila adanya kerjasama antara guru, siswa dan orang tua dalam belajar di rumah.

PAUD Telkom Ternate merupakan salah satu lembaga pendidikan yang menerapkan kebijakan pemerintah untuk belajar melalui jaringan (daring) atau Belajar Dari Rumah (BDR) selama masa pandemi berlangsung. Pembelajaran daring (online) diartikan sebagai suatu jaringan komputer yang saling terkoneksi dengan jaringan komputer lainnya keseluruh penjuru . Proses pembelajaran daring ini telah diberlakukan di PAUD Telkom Ternate sejak tanggal 28 Maret 2020 sebagai bentuk pencegahan penyebaran Covid-19. Namun selama proses pembelajaran daring tidak sedikit masalah yang terjadi dalam pelaksanaannya, baik masalah dari anak, orang tua maupun guru.

Pada kenyataannya masalah yang dihadapi anak selama pembelajaran daring yaitu kebosanan saat melaksanakan proses pembelajaran karena anak harus selalu menyimak video arahan pelaksanaan tugas yang diberikan oleh guru yang sama tanpa adanya interaksi secara langsung. Hal ini juga berdampak bagi kesehatan anak seperti 
kesehatan mata. Sebelum adanya pembelajaran daring anak dilarang untuk menggunakan handphone tetapi berbeda dengan masa pandemi saat ini yang membuat anak cenderung berdampingan dengan handphone. Sedangkan masalah yang dialami oleh guru yaitu tidak efektifnya proses penyampaian pembelajaran melalui video karena dibatasi oleh durasi waktu. Selain itu kendala juga terjadi pada saat proses penilaian dan pengamatan yang tidak maksimal terhadap perkembangan anak karena guru hanya melihat dari video dan lembar hasil belajar anak. Berbeda dengan selama proses pembelajaran disekolah dengan cara tatap muka, anak lebih aktif dan bersemangat karena bisa belajar sambil bermain bersama teman-teman serta guru dapat mengontrol dan memberikan arahan kepada anak secara langsung, selain itu guru dapat lebih mudah mengamati dan menilai perkembangan anak selama proses pembelajaran berlangsung.

Selama proses pembelajaran daring pengoptimalan peran orang tua juga sangat penting. Peran orang tua yang pada awalnya adalah memberikan dasar pendidikan, sikap dan keterampilan dasar, seperti pendidikan sopan, santun, dan dasar-dasar untuk mematuhi perintah, namun kini perannya menjadi meluas yaitu sebagai pendamping pendidikan akademik. Kemudian masalah yang muncul pada orang tua yaitu tentang manajemen waktu antara bekerja dan mendampingi anak karena kesibukan yang berbeda-beda. Selain itu keterbatasan pengetahuan, pemahaman terhadap instuksi yang diberikan oleh guru, sulitnya menumbuhkan minat belajar anak dan cara teknis penggunaan teknologi menjadi salah satu kendala dalam sistem daring ini karena pada situasi ini orang tua dituntut untuk membimbing anak-anak dalam pembelajaran berbasis internet. Bagi orang tua siswa yang terbiasa menggunakan teknologi mungkin tidak menjadi masalah tetapi bagi orang tua yang awam akan penggunaan teknologi menjadi tantangan tersendiri dalam membimbing anaknya kala situasi ini.

Bentuk perkembangan teknologi informasi yang dimanfaatkan sebagai media pembelajaran di PAUD Telkom Ternate adalah aplikasi Whatsapp. Keunggulan aplikasi whatsaap yaitu mudah dalam penggunaannya, fleksibel waktu, serta menyediakan berbagai konten seperti dapat mengirim dan menerima pesan, foto, video, rekam suara, dokumen, dan dapat melakukan panggilan video. Namun dalam konten panggilan video whatsapp membatasi jumlah orang didalamnya.

Beberapa penelitian relevan yang telah disebutkan diatas memiliki kesamaan dengan penelitian yang akan dilakukan ini yaitu sama-sama meneliti tentang dampak Covid-19 terhadap proses pembelajaran daring khususnya pada pendidikan anak usia dini. Adapun penelitian ini bertujuan untuk menjelaskan tentang analisis dampak Covid-19 dalam proses pembelajaran daring di PAUD Telkom Ternate.

\section{B. Tinjauan Pustaka}

Covid-19 adalah penyakit menular yang disebabkan oleh virus korona yang paling baru ditemukan. Virus dan penyakit baru ini tidak diketahui sebelum wabah dimulai di Wuhan, Cina, pada Desember 2019. Covid-19 sekarang menjadi pandemi yang menyerang banyak negara secara global, (who.int, 2020). Coronavirus jenis baru yang ditemukan pada manusia sejak kejadian luar biasa muncul di Wuhan Cina pada Desember 2019, kemudian diberi nama Severe Acute Respiratory Syndrome Coronavirus 2 (SARS-COV2), dan menyebabkan penyakit Coronavirus Disease-2019 (Covid-19). Gejala umum berupa demam 380C, batuk kering, dan sesak napas. Jika ada orang yang dalam 14 hari sebelum muncul gejala tersebut pernah melakukan perjalanan ke negara terjangkit, atau pernah merawat/kontak erat dengan penderita Covid-19, maka terhadap orang tersebut akan dilakukan pemeriksaan laboratorium lebih lanjut untuk memastikan diagnosisnya (Kemendagri, 2020). 
Cara penularan utama penyakit ini adalah melalui tetesan kecil (droplet) yang dikeluarkan pada saat seseorang batuk atau bersin. WHO menilai bahwa risiko penularan dari seseorang yang tidak bergejala Covid-19 sama sekali sangat kecil kemungkinannya. Namun, banyak orang yang teridentifikasi Covid-19 hanya mengalami gejala ringan seperti batuk ringan, atau tidak mengeluh sakit, yang mungkin terjadi pada tahap awal penyakit. Selain itu covid-19 paling utama ditransmisikan oleh tetesan aerosol penderita dan melalui kontak langsung. Aerosol kemungkinan ditransmisikan ketika orang memiliki kontak langsung dengan penderita dalam jangka waktu yang terlalu lama. Konsentrasi aerosol di ruang yang relatif tertutup akan semakin tinggi sehingga penularan akan semakin mudah.

Kemenkes Indonesia, (2020) memberikan beberapa cara yang bisa dilakukan untuk mencegah penularan virus ini adalah menjaga kesehatan dan kebugaran agar stamina tubuh tetap prima dan sistem imunitas/kekebalan tubuh meningkat. Mencuci tangan dengan benar secara teratur menggunakan air dan sabun atau hand-rub berbasis alkohol.

\section{Metodologi}

Metode yang digunakan dalam penelitian ini adalah kualitatif deskriptif yaitu penelitian yang ditujukan untuk mendeskripsikan dan menganalisis suatu fenomena atau aktivitas sosial. Menurut Carbin dan Strauss (dalam Wahid: 2017) metode penelitian kualitatif adalah bentuk penelitian dimana peneliti mengumpulkan dan menganalisis data menjadi bagian dari proses penilaian sebagai partisipan bersama informan yang memberikan data.Subjek dalam penelitian ini adalah orang tua wali murid kelompok kelas B4 dengan jumlah 5 orang (4 Wali murid, 1 Guru kelas). Teknik pengumpulan data yang digunakan adalah wawancara dan dokumentasi yang mengacu pada pertanyaan penelitian yang telah di tetapkan, dimana pelaksanaan proses analisis data dilakukan secara teratur melalui proses pengumpulan data, reduksi data, penyajian data, dan penarikan kesimpulan.

\section{Hasil dan Pembahasan}

Munculnya pandemik Covid-19 kegiatan belajar mengajar yang semula dilaksanakan di sekolah kini menjadi belajar di rumah melalui daring. Pembelajaran daring dilakukan dengan disesuaikan kemampuan masing-maising sekolah, karena selama pembelajaran daring, Kemendikbud menyerahkan penyesuaian kurikulum kepada guru dan kepala sekolah sesuai dengan konsep merdeka belajar, seperti yang di katakan oleh Ketut, (2020) selama pandemi Covid-19 berlangsung telah menyebabkan penyesuaian dibidang pendidikan.

Di PAUD Telkom Ternate, pembelajaran daring telah diaksanakan pada akhir bulan april setelah diliburkannya sekolah selama 2 minggu sesuai dengan arahan Kemendikbud. Dalam hal ini kerjasama antara orang tua dan guru sangat mempengaruhi dalam terlaksananya pembelajaran daring.

Munculnya Covid-19 ini menunjukkan semakin pentingnya peran orang tua dalam membimbing anak belajar dirumah menggantikan tugas guru disekolah. Namun hal ini menjadi kejutan besar bagi para orang tua, terlebih yang tidak biasa mendampingi anak belajar di rumah yang tentu saja menimbulkan berbagai masalah atau kendala baru yang dialami oleh orang tua, seperti kurangnya pemahaman materi oleh orang tua, kesulitan orang tua dalam menumbuhkan minat belajar anak, tidak memiliki cukup waktu untuk mendampingi anak karena harus bekerja, orang tua tidak sabar dalam mendampingi anak saat belajar dirumah, oleh karena itu perubahan membutuhkan waktu untuk bisa berjalan optimal. 
Masalah-masalah tersebut dapat terjadi karena selama ini orang tua hanya melihat perkembangan anak tanpa turun tangan untuk mendampingi anak belajar. Hal ini dikarenakan orang tua lebih memberatkan pendidikan anak kepada sekolah karna menganggap bahwa pendidikan itu merupakan tanggung jawab satu pihak saja yaitu lembaga sekolah dan mengabaikan bahwa sebenarnya pendidikan utama yaitu berada pada keluarga. Sebagaimana yang dipaparkan oleh Rosdiana, (2006) bahwa faktanya kebanyakan orang tua merasa bahwa kewajibannya dalam mendidik anak telah usai setelah memasukkannya ke suatu lembaga persekolahan.

Selain orang tua dan anak, kendala juga dialami oleh guru selama pembelajaran daring berlangsung. Guru kelas B4 (Ml) menyatakan bahwa beberapa kendala terjadi selama pembelajaran berlangsung seperti terbatasnya dalam penyampaian materi, sulitnya melakukan pengamatan dan penilaian karena guru hanya melihat perkembangan anak melalui foto, video, dan lembar hasil belajar anak. Hal ini tentunya membuat guru kesulitan dalam melakukan penilaian karena mengingat belajar dirumah tentunya tidak terlepas dari bantuan orang tua.

Setiap guru memiliki teknik dan cara yang berbeda-beda dalam pelaksanaan pembelajaran daring. Selama pembelajaran daring berlangsung banyak orang tua yang mengatakan bahwa pemberian tugas dinilai mampu membantu siswa dalam mengurangi rasa stres pada anak karena media yang diberikan menyenangkan dan dinilai tidak sulit karena anak sudah pernah mendapatkan pelajaran serupa saat masih berada di bangku kelompok A. Dalam pembelajarannya pun guru menyesuaikan dengan lingkungan sekitar anak atau dekat dengan anak.

Mengingat mood anak yang sering berubah-ubah, guru tidak membatasi waktu dalam pengerjaan tugas, artinya tugas bisa diksetorkan mulai padi hingga malam dalam bentuk foto atau video dengan cara mengirimkan melalui aplikasi whatsapp yang digunakan dalam pembelajaran daring ini selain foto dan video, hasil belajar anak juga di kumpulkan di sekolah pada hari jum'at pula. Artinya dalam pengambilan media pembelajaran untuk satu minggu kedepannya, orang tua juga harus mengumpulkan hasil belajar anak selama satu minggu sebelumnya.

Meski terkesan membosankan, pembelajaran daring memiliki banyak manfaat bagi keluarga salah satunya adalah mengembalikan fungsi keluarga sebagai tempat pendidikan pertama dan utama. Zahrok \& Sumarmini (2018) menyatakan bahwa keluarga menjadi satu bagian yang paling penting dalam pendidikan, keluarga menjadi salah satu pusat pendidikan untuk anak. Pembelajaran daring memenjadikan komunikasi orang tua dan anak semakin dekat, orang tua yang sebelumnya tidak memiliki waktu untuk mendampingi anak, kini selamama pembelajaran daring orang tua meluangkan waktu untuk mndampingi anak belajar. Selama mendampingi anak belajar orang tua menjadi tahu bagaimana perkembangan anak, cara belajar yang disukai anak, dan pelajaran apa yang disukai oleh anak. Namun tak hanya sampai situ, orang tua juga dihadapkan dengan karakter anak yang tidak hanya menurut saja tetapi juga dihadapkan dengan karakter anak yang sulit untuk diajak belajar. Selain itu selama pembelajaran daring orang tua lebih mengeluh stres karena selain harus bekerja di luar rumah juga harus mendampingi anak belajar serta mengurus keluarga.

Menurut Agus, dkk dalam penelitiannya yang berjudul "Studi Eksploratif Dampak Pandemi Covid-19 Terhadap Proses Pembelajaran online di Sekolah Dasar" dampak Covid-19 terhadap proses pembelajaran online di sekolah dasar berdampak terhadap siswa, orang tua dan guru itu sendiri. Beberapa dampak yang dirasakan murid yaitu murid belum ada budaya belajar jarak jauh karena selama ini sistem belajar dilaksanakan adalah melalui tatap muka, murid terbiasa berada di sekolah untuk berinteraksi dengan teman-temannya, bermain dan bercanda gurau dengan teman-temannya serta bertatap muka dengan para gurunya, dengan adanya metode pembelajaran jarah jauh membuat para murid perlu waktu untuk beradaptasi dan 
mereka menghadapi perubahan baru yang secara tidak langsung akan mempengaruhi daya serap belajar mereka. Tak hanya itu, anak juga mengalami korban kekerasan verbal, kehilangan semangat belajar, penurunan capaian perkembangan, anak beresiko kehilangan pembelajaran, anak juga mengalami jenuh dan stres karena hilangnya kesempatan bermain bebas atau secara fisik dengan teman sebayanya, tidak dapat melakukan hobi atau kegiatan reaksional lainnya diluar rumah.

Pemahaman materi yang luas yang dimiliki oleh orang tua sangat bermanfaat dalam membantu anak belajar dirumah. Orang tua membantu anak belajar dirumah berdasarkan kegiatan yang ada disekolah, seperti membacakan buku cerita yang mendidik dan membantu anak mengerjakan tugas-tugas dari sekolah (Diadha, 2020). Pembelajaran tidak bisa maksimal jika orang tua belum sepenuhnya memahami materi yang diberikan oleh guru untuk diajarkan kepada anak, seperti yang diungkapkan oleh penelitian sebelumnya bahwa bahwa orang tua harus benar benar menguasai materi pembelajaran yang diberikan oleh guru agar terlaksananya pendidikan dirumah menjadi sukses (Irma et al., 2019). Hal ini sependapat dengan penelitian yang dilakukan oleh Irhamnna yang menyatakan bahwa peran orang tua dalam memahami materi yang di berikan dari pihak sekolah sangat penting dalam meningkatkan kualitas pembelajaran anak (Irhamna, 2016.).

Dalam berlangsungnya pemberlajaran daring whatsapp sebagai media online ini dinilai mudah dalam pengaksesannya. Selain itu di jaman saat ini whatsapp mesenger sangat familier dalam kehidupan sehari-hari karena whatsapp menyediakan berbagai konten yang cukup lengkap. WhatsApp juga aplikasi dengan jumlah pengguna yang sangat besar (Pertiwi, 2020). Dalam whatsApp terdapat berbagai konten seperti dapat melakukan panggilan suara, panggilan video (hanya 4 anggota), berbagi dokumen, mengirim dan menerima foto, video dan audio, dapat mengakses kamera dan galeri, mengirim dan menerima video youtube box, mengirim dan menerima file dalam bentuk microsoft. Selain itu whatsapp juga menyediakan konten grup chat yang memungkinkan memuat hingga 500 anggota di dalamnya. Dalam penggunaan media sosial juga dapat dengan mudah menciptakan suatu forum dimana individu satu dengan yang lain dapat saling berkomunikasi dan bertukar pikiran satu sama lain, Hemawan (2009). Hal ini yang membuat orang tua memilih whatsapp sebagai media platform dalam pembelajaran daring dibandingkan dengan platform lain.

Melalui whatsapp guru menjadi mudah dalam menyampaikan informasi, memberikan instruksi, bahkan saat memberikan dukungan kepada anak. Selama pembelajaran daring berlangsung tak hentinya guru dalam memberikan semangat dan motivasi kepada anak. Dari hasil penelitian yang telah peneliti lakukan, orang tua mengungkapkan bahwa dukungan yang diberikan kepada anak selain bentuk fisik berupa media pembelajaran juga dalam bentuk motivasi agar anak selalu semangat belajar.

\section{E. Kesimpulan}

Berdasarkan hasil temuan lapangan tentang Analisis Dampak Covid-19 Dalam Proses Pembelajaran daring di PAUD Telkom Ternate, maka kesimpulan dalam penelitian ini adalah terkait tentang dampak negatif Covid-19 diantaranya adalah berdampak psikis terhadap orang tua dan juga anak yaitu berupa stres. Selain itu, anak menjadi korban kekerasan verbal, kehilangan semangat belajar, penurunan capaian perkembangan, anak beresiko kehilangan pembelajaran. Sedangkan dampak yang terjadi pada guru adalah kurang optimalnya proses penilaian perkembangan pada anak. Namun selain dampak negatif, pembelajaran daring juga memiliki dampak poritif yaitu kembalinya fungsi keluarga sebagai pendidikan utama, menjadikan hubungan antara orang tua dan anak semakin dekat, orang tua menjadi tahu 
bagaimana karakter anak, mengetahui bagaimana cara mengajar anak, mengetahui belajar yang disukai anak, membuat orang tua lebih mudah dalam memonitoring/mengawasi perkembangan belajar anak, mengajarkan kepada anak dalam memanfaatkan teknologi untuk hal yang bermanfaat dan menghindari mengakses hal-hal yang tidak bermanfaat, menjamin kebersihan dan kesehatan anak.

Selama pelaksanaan proses pembelajaran daring tentunya tak selalu berjalan dengan baik namun ada beberapa hambatan yang terjadi seperti mood anak yang berubah-ubah/tidak selalu baik. Sedangkan hambatan yang muncul pada pada orang tua yaitu tidak memiliki cukup waktu untuk mendampingi anak belajar karena harus bekerja, sulitnya menumbuhkan minat belajar anak. Hambatan juga terjadi pada guru yaitu sulitnya melakukan penilaian karena hanya melihat perkembangan anak melalui foto, video, dan hasil karya anak/unjuk kerja.

\section{DAFTAR PUSTAKA}

Aji, R. H. S. 2020. Dampak Covid-19 pada Pendidikan Indonesia: sekolah, keterampilan, dan Proses Pembelajaran. Jurnal Sosial \& Budaya Syar-i Vol. 7 No. 5 (2020), pp. 395402. Diakses pada tanggal 05 Agustus 2020 http://journal.uinjkt.ac.id/index.php/salam/article/view/15314

Akbar, E. 2020. Metode Belajar Anak Usia Dini. Jakarta: Kencana

Ali, Z.Z. 2020. Peran Dan Fungsi Keluarga Dalam Pendampingan Pendidikan Anak Ditengah Pandemi Covid-19. JSGA Vol. 02 No. 01. Diakses pada tanggal 30 Novermber 2020. https://e-journal.metrouniv.ac.id/index.php/jsga/article/view/2379

Anita, W., Ayriza,Y. 2020. Analisis Kendala Orang Tua dalam Mendampingi Anak Belajar di Rumah Pada Masa Pandemi Covid-19. Jurnal Obsesi. Volume 5 Issue 1 (2021) Pages 772-782. Diakses pada tanggal 28 Oktober 2020. 10.31004/obsesi.v5i1.705

Anugraha, A. 2020. Hambatan, Solusi dan Harapan: Pembelajaran Daring Selama Masa Pandemi Covid-19 Oleh Guru Sekolah Dasar. Jurnal Pendidikan dan Kebudayaan, Vol. 10 No. 3, 282-289. Diakses pada tanggal 28 Oktober 2020. https://ejournal.uksw.edu

Azizah, N.F. 2020. Strategi Menghidupkan Motivasi Belajar Anak Usia Dini Selama Pandemi COVID-19 melalui Publikasi. Jurnal Obsesi: Jurnal Pendidikan Anak Usia Dini. Volume 5 Issue 1 (2021) Pages 373-384. Dakses pada tanggal 2 Januari 2021. Yogyakarta.

Barseli, M. dkk. 2020. Konsep Stres Akademik Siswa. Jurnal Konseling dan Pendidikan. Volume 5 Nomor 3, 2017, Hlm 143-148. Diakses pada tanggal 2 November 2020.

Biki N. L. 2015. Pelaksanaan Program Parenting Kelompok Bermain (Kb) Prima Sanggar Dalam Mendorong Keterlibatan Orang Tua Pada Pendidikan Anak. Skripsi. Fakultas ilmu Pendidikan. Jurusan Pendidikan Luar Sekolah. Universitas Negeri Yogyakarta. Yogyajarta.

Briliannur, Dwi C. Dkk. 2020. Analisis Keefektifan Pembelajaran Online di Masa Pandemi Covid-19. Jurnal Pendidikan Guru Sekolah dasar. Diakses pada tanggal 2 Januari 2021 
Dewi, W. A. F. 2020. Dampak covid-19 terhadap implementasi pembelajaran daring di sekolah dasar. Jurnal Ilmu Pendidikan Volume 2 Nomor 1 April 2020 Halm 55-61. https://edukatif.org/index.php/edukatif/article/view/89/pdf. Diakses pada tanggal 3 Agustus 2020.

Gusti, S. dkk. 2020. Belajar Mandiri: Belajar Daring di Tengah Covid-19. Yayasan Kita Bisa Menulis.

Hafidz, M. N. 5 September 2020. Dampak Psikologis Belajar dari Rumah bagi Anak dan Orang Tua. https://ayobandung.com/read/2020/07/14/106417/dampakpsikologis-belajar-dari-rumah-bagi-anak-dan-orang-tua

Jr, Fahrur. 2020. Efektivitas Pembelajaran. Mas Firda

Kementerian Kesehatan Republik Indonesia. 2020. Dokumen Resmi dan Protokol Penanganan COVID-19. Diakses pada tanggal 2 Agustus 2020 https://www.kemkes.go.id/article/view/20031700001/Dokumen-Resmi-danProtokol-Penanganan-COVID-19.html.

Kementerian Kesehatan Republik Indonesia. 2020. Situasi Terkini Perkembangan Coronavirus Disease (COVID-19) 8 Mei 2020. Diakses pada tanggal 6 Agustus 2020 https://covid19.kemkes.go.id/situasi-infeksi-emerging/info-corona-virus/situasiterkini-perkembangan-coronavirus-disease-covid-19-8-mei-2020/\#.X0tjX5kxXIV

Kementerian Pendidikan dan Kebudayaan. 2020. Kemendikbud Bekerja Sama dengan Operator Telekomunikasi Sukseskan Pembelajaran di Rumah. diakses pada tanggal 1 agustus 2020. https://www.kemdikbud.go.id/main/blog/2020/03/kemendikbudbekerja-sama-dengan-operator-telekomunikasi-sukseskan-pembelajaran-dirumah.

Kementerian Pendidikan dan Kebudayaan. 2020. Kemendikbud Terbitkan Pedoman Penyelenggaraan Belajar dari Rumah. Diakses pada tanggal 9 Agustus2020 https://www.kemdikbud.go.id/main/blog/2020/05/kemendikbud-terbitkanpedoman-penyelenggaraan-belajar-dari-rumah

Kepala Badan Penanggulangan Bencara No. 13. A Tahun 2020 Tentang Perpanjangan Status Keadaan Tertentu Darurat Bencana Wabah Penyakit Akibat Virus Corona di Indonesia.

Makdori, Y. 2020. Nadiem Beberkan Manfaat Belajar dari Rumah Selama Pandemi Corona. Diakses pada tanggal 9 Agustus 2020. https://www.liputan6.com/news/read/4254998/nadiem-beberkan-manfaatbelajar-dari-rumah-selama-pandemi-corona

Nurdin., dan Anhusadar, L.O. 2020. Efektivitas Pembelajaran Online Pendidik PAUD di Tengah Pandemi Covid 19. Jurnal Pendidikan Anak Usia Dini. Volume 5 Issue 1. $\begin{array}{llll}\text { Diakses } & \text { pada } & \text { tanggal } & 2020 .\end{array}$ https://obsesi.or.id/index.php/obsesi/article/view/699

Nurkholis. 2020. Dampak Pandemi Novel-Corona Virus Disiase (Covid-19) Terhadap Psikologi Dan Pendidikan Serta Kebijakan Pemerintah. Jurnal PGSD. Volume 6 (1) 
$\begin{array}{llllll}\text { Januari } & \text {-Juni } 2020 & 128 & \text { Oktober } 2020 . & \text { https://e- }\end{array}$ journal.umc.ac.id/index.php/JPS/article/view/1035/713

Peraturan Pemerintah Republik Indonesia Nomor 21 tahun 1994 Tentang Penyelenggaraan pembangunan Keluarga Sejahtera

Pohan, A.E. 2020. Konsep Pembelajaran Daring Berbasis Pendekatan Ilmiah. Jawa Tengah. CV Saru Untung

Prajana, A. 2017. Pemanfaatan Aplikasi Whatsapp Dalam Media Pembelajaran di Uin ArRaniry Banda Aceh. Jurnal Pendidikan Teknologi Informasi. volume 1, nomor 2. Diakses pada tanggal 2 november 2020. https://jurnal.ar-raniry.ac.id

Pujiastuti, S. 3 Juli 2020. Dampak Covid-19 Terhadap Pendidikan Anak. Surveymeter.org. hal 1. Diakses pada tanggal 1 januari 2020. https://surveymeter.org/id/node/568

Purwanto, A. dkk. Studi Eksploratif Dampak Pandemi COVID-19 Terhadap Proses Pembelajaran Online di Sekolah Dasar. Jurnal Edupsycoun.s Volume 2 No. 1 (2020), ISSN Online hlm 2716 - 4446. Diakses pada tanggal 3 Agustus 2020 https://ummaspul.e-journal.id/Edupsycouns/article/view/397/223.

Putria,H. dkk. 2020. Analisis Proses Pembelajaran Dalam Jaringan (DARING) Masa Pandemi COVID-19 pada Guru Sekolah Dasar. Jurnal Basicedu Volume 4 Nomor 4 Tahun 2020 Halm. 861 - 872. Diakses pada tanggal 2 Agustus 2020. http://jbasic.org/index.php/basicedu/article/view/460/pdf

Rini, A. dkk. Teaching From Home. Yayasan Kita Menulis

Sit, M dan Assingkily, M.S. 2020. Persepsi Guru tentang Social Distancing pada Pendidikan AUD Era New Normal. Jurnal Obsesi : Jurnal Pendidikan Anak Usia Dini. Volume 5 Issue 2 (2021) Pages 1009-1023. Diakses pada tanggal 30 desember 2020

Suardi, Moh. 2018. Belajar dan Pembelajaran. Yogyakarta: Cv Budi Utama

Subarto. 2020. Momentum Keluarga Mengembangkan Kemampuan Belajar Peserta Didik Di Tengah Wabah Pandemi Covid-19. Adalah: Buletin Hukum dan Keadilan. Vol. 4, No. 1. Diakses pada tanggal 2 November 2020. http://journal.uinjkt.ac.id/index.php/adalah/article/view/15383/7184

Sudarsa, Ketut, dkk. 2020. Covid-19: Persepsi Pendidikan. Yayasan Kita Bisa Menulis

Susilo, A. dkk. 2020. Coronavirus Disease 2019: Tinjauan Literatur Terkini. urnal Penyakit Dalam Indonesia | Vol. 7, No. 1. Diakses pada tanggal 5 Agustus2020 https://ocw.ui.ac.id/pluginfile.php/2469/mod_resource/content/3/415-1924-1PB.pdf.pdf.

Sutopo, E. dkk. 2020. Selaksa Rasa KBM Online. Jawa Tengah: Omera Pustaka

Tabi'in, A. 2020. Problematika Stay At Home Pada Anak Usia Dini Di Tengah Pandemi Covid 19. Jurnal Golden Age. Diakses pada tanggal 28 Oktober 2020.http://ejournal.hamzanwadi.ac.id/index.php/jga/article/download/2244/1298 
UNICEF. 2020. COVID-19 dan Anak-anak di Indonesia. Diakses pada tanggal 3 Agustus 2020 https://www.unicef.org/indonesia/id/laporan/covid-19-dan-anak-anak-diindonesia.

UNICEF. 2020. COVID-19: Anak-anak di Indonesia Berisiko Mengalami Konsekuensi Jangka Panjang. Diakses pada tanggal 3 Agustus 2020 https://www.unicef.org/indonesia/id/press-releases/covid-19-anak-anak-diindonesia-berisiko-mengalami-konsekuensi-jangka-panjang.

Wahidmurni. 2017. Pemaparan Metode Kualitatif. Fakultas Ilmu Tarbiyah dan Keguruan UIN Maulana Ibrahim Malang. Diakses pada tanggal 6 Agustus 2020 http://repository.uin-malang.ac.id/1984/2/1984.pdf

Wardhani, I.K. 2020. Menjaga Kesehatan Mental Anak Selama Stay At Home. Diakses pada tanggal 10 Agustus 2020 http://puspensos.kemsos.go.id/menjaga-kesehatanmental-anak-selama-stay-at-home

WHO. 2020. Pertanyaan dan Jawaban Terkait Coronavirus. Diakses pada tanggal 9 Agustus 2020 https://www.who.int/indonesia/news/novel-coronavirus/qa-for-public

Worldometers. 2020. COVID-19 Coronavirus Pandemic. Diakses pada tanggal 2 Agustus 2020 https://www.who.int/indonesia/news/novel-coronavirus/qa-for-public

Yuliana. 2020.Corona Virus Diseases (covid-19). Jurnal Wellness and Healthy Magazine Volume 2, No.1 (2020). Diakses pada tanggal 5 Agustus 2020 https://wellness.journalpress.id/wellness/article/view/21026/pdf.

Yuliani, M., dkk. 2020. Pembelajaran Daring Untuk Pendidikan. Medan: Yayasan Kita Bisa Menulis.

Yunus, N.R., dan Annissa,R. 2020. Kebijakan Pemberlakuan Lock Down Sebagai Antisipasi Penyebaran Corona Virus Covid-19. Jurnal Sosial dan Budaya Syar'i Volume 7, No. 3 (2020), pp.227-238. Diakses pada tanggal 3 Agustus 2020 http://journal.uinjkt.ac.id/index.php/salam/article/view/15083/pdf.

Za, Safrizal. dkk. 2020. Pedoman Umum Menghadapi Pandemi Covid-19. Diakss pada tanggal 5 Agustus 2020 https://www.kemendagri.go.id/documents/covid9/BUKU_PEDOMAN_COVID-19_KEMENDAGRI.pdf. 